DOI : https://doi.org/10.47828/iianaasian.v9i1.51

\title{
Inovasi Pelayanan Administrasi Nikah Terintegrasi di Kantor Urusan Agama Kecamatan Enam Lingkung Kabupaten Padang Pariaman
}

\author{
Nugi Alindro' ${ }^{1}$, Kusdarini ${ }^{2}$, Roni Ekha Putera ${ }^{3}$ \\ ${ }^{123}$ Jurusan Administrasi Publik, Universitas Andalas, Kota Padang, Indonesia
}

ART I C LE IN F O

Article history:

Received 04/02/2021

Received in revised form 03/03/2021

Accepted 26/03/2021

\begin{abstract}
Purpose of this study to describe the Integrated Marriage Administration Service Innovation (PANTER) by KUA Kecamatan Enam Lingkung, Padang Pariaman. Public service innovation doesn't not require a something new, but can be a new approach in contextual at the sense that innovation not limited from there are ideas and practicies of innovation but can be in the form of innovation resulting from expansion or quality improvement of existing innovations. This research is using descriptive approach by qualitative methods. Technique of collecting the data was by interview and documentation.This study is motivated by good will from Head of KUA Kecamatan Enam Lingkung to make easier community of Enam Lingkung District to get some documents and to assist Disduckcapil Kabupaten Padang Pariaman in orderly administration. The result of this study is PANTER helped community to obtaining marriage documents and population documents like Nationality ID, Family Register, and Nationality Health Insurance without spending money and time. However, there are still some problem faced by the community and PANTER officer, such as lack of facilities and infrastructure, lack of PANTER officer and unstable internet networks.
\end{abstract}

Keywords: Innovation, Public Service, PANTER

\begin{abstract}
Abstrak
Tujuan penelitian ini adalah untuk mendeskripsikan Inovasi Pelayanan Administrasi Nikah Terintegrasi (PANTER) di Kantor Urusan Agama Kecamatan Enam Lingkung Kabupaten Padang Pariaman. Inovasi pelayanan publik sendiri tidak mengharuskan suatu penemuan baru, tetapi dapat merupakan suatu pendekatan baru yang bersifat kontekstual dalam arti inovasi tidak terbatas dari tidak ada kemudian muncul gagasan dan praktik inovasi, tetapi dapat berupa inovasi hasil dari perluasan maupun peningkatan kualitas pada inovasi yang ada. Pendekatan dalam penelitian ini adalah deskriptif kualitatif. Sumber data primer dan sekunder. Teknik pengumpulan data yang digunakan adalah wawancara dan dokumentasi. Penelitian ini dilatar belakangi oleh keinginan Kepala KUA Kecamatan Enam Lingkung untuk mempermudah masyarakat dalam mendapatkan dokumen serta membantu Disdukcapil Kabupaten Padang Pariaman dalam tertib administrasi. Hasil penelitian menunjukan bahwa inovasi PANTER membantu masyarakat dalam mendapatkan dokumen pernikahan dan dokumen kependudukan seperti Buku Nikah, KTP,KK dan BPJS tanpa mengeluarkan biaya dan tenaga. Namun masih terdapat beberapa kendala yang dihadapi oleh
\end{abstract}


masyarakat dan petugas PANTER seperti sarana dan prasana yang kurang memadai dan jaringan internet yang tidak stabil serta kurangnya petugas inovasi PANTER tersebut.

Kata kunci: Inovasi, Pelayanan Publik, Administrasi Nikah

${ }^{*}$ Penulis Korespondensi

E-mail : roniekhaputera@soc.unand.ac.id

\section{PENDAHULUAN}

Pada dasarnya manusia membutuhkan pelayanan, konsep pelayanan ini akan selalu ada pada kehidupan setiap manusia. Posisi masyarakat yang menjadi warga negara membuat penyedia pelayanan publik tidak hanya memposisikan masyarakat sebagai yang dilayani tetapi juga dilibatkan dalam pengambilan keputusan. Peran serta masyarakat dalam proses pengambilan keputusan memungkinkan para penyedia pelayanan publik lebih responsif terhadap masyarakat adalah munculnya inovasi pelayanan. Pelayanan publik yang optimal belum dapat direalisasikan di Indonesia, kondisi pelayanan publik di Indonesia masih sangat rendah (Djamrut, 2015).

Perubahan pelayanan dalam bentuk inovasi menjadi keharusan dalam pelayanan publik. Inovasi pelayanan publik merupakan terobosan pelayanan publik yang merupakan ide kreatif yang memberikan manfaat bagi masyarakat secara langsung maupun tidak langsung (Yuliana, 2020). Inovasi berhasil apabila terdapat kreasi dan implementasi dari proses, produk, layanan dan metode pelayanan baru yang merupakan hasil dari pengembangan efisiensi, efektivitas atau kualitas hasil (Muluk, 2008). Dengan kata lain, inovasi pelayanan publik sendiri tidak mengharuskan suatu penemuan baru, tetapi dapat merupakan suatu pendekatan baru yang bersifat kontekstual dalam arti inovasi tidak terbatas dari tidak ada kemudian muncul gagasan dan praktik inovasi, tetapi dapat berupa inovasi hasil dari perluasan maupun peningkatan kualitas pada inovasi yang ada (PERMENPAN dan RB Nomor 30 Tahun 2014), sedangkan menurut Evert $M$. Roger inovasi adalah ide, gagasan, praktik atau/benda yang didasari dan diterima sebagai suatu hal yang baru oleh seseorang atau kelompok untuk diadopsi (Suwarno, 2008)

Upaya untuk meningkatkan efektifitas pelayanan publik terutama dalam administrasi kependudukan pada masyarakat, pemerintah harus menjamin akurasi data kependudukan dan ketunggalan Nomor Induk Kependudukan (NIK) serta ketunggalan dokumen kependudukan yang mana artinya masyarakat di indonesia tidak boleh mempunyai identitas yang berbeda dalam suatu dokumen.

Salah satu dokumen kependudukan yang paling penting bagi masyarakat Indonesia adalah adalah Kartu Tanda Penduduk (KTP) yang mana didalamnya terdapat informasi tentang kependudukan masyarakat, namun pembuatan EKTP di Indonesia mempunyai kendala dalam birokrasinya, salah satunya adalah proses birokrasi yang mengharuskan pemerintah provinsi menunggu blangko dari pemerintah pusat, sehingga tidak bisa membuat blangko sendiri (tirto.id, 2018)

Permasalahan yang terjadi pada tahun 2018 tersebut terjadi 
karena reformasi politik yang dilakukan pemerintah belum diikuti oleh reformasi birokrasi, maka dengan demikian pemerintah harus memikirkan kualitas pelayanan dalam pemenuhan kebutuhan masyarakat (Ananda, 2019)

Pada Provinsi Sumatera Barat, tepatnya di Kabupaten Padang Pariaman dalam peningkatan pelayanan publik salah satu nya yaitu KUA Kecamatan Enam Lingkung memberikan pelayanan yang mengayomi masyarakat dengan menerapkan pelayanan yang prima dan berkualitas. Dalam rangka mendekatkan pelayanan kepada masyarakat, dan menerapkan pelayanan yang prima dan berkualitas, KUA Kecamatan Enam Lingkung menerapkan Prinsip koordinasi, integrasi dan sinkronisasi baik dalam lingkungan KUA Kecamatan Enam Lingkung sendiri maupun dengan lembaga lain yang terkait. Oleh sebab itu KUA Kecamatan Enam Lingkung memiliki komitmen yang besar terhadap peningkatan pelayanan berkualitas kepada masyarakat. Dengan motto "Tegas dengan Peraturan, Ramah dalam Pelayanan".

KUA Kecamatan Enam Lingkung menawarkan pelayanan kepada masyarakat dengan PASTI, pasti persyaratannya, pasti waktunya, pasti biayanya yang dibungkus dengan karakter petugas pelayanan yang Profesional, Amanah, Senyum, Transparan dan Inovatif menjadi acuan dalam mewujudkan pelayanan yang berkualitas "Bersih Melayani". Pelayanan yang diberikan kepada setiap warga atau masyarakat yang berurusan ke KUA Kecamatan Enam Lingkung lebih mengedepankan Pelayan Prima. Pelayanan Prima telah diterapkan dalam bentuk pelayanan yang cepat, tepat, sistematis, prosedural, ramah, jujur, serta ikhlas dalam melayani.

Salah satu cara mewujudkan hal tersebut dan sebagai bentuk implementasi dari Undang-Undang Nomor 25 tahun 2009 tentang Pelayanan Publik dan UndangUndang Nomor 24 tahun 2013 tentang Administrasi Kependudukan, KUA Kecamatan Enam Lingkung meluncurkan sebuah inovasi pelayanan yaitu Pelayanan Administrasi Nikah Terintegrasi atau dikenal dengan istilah PANTER. PANTER merupakan pelayanan yang lahir dari kesepakatan bersama antara kepala KUA, Camat Enam Lingkung dan Kepala Kantor Dinas Kependudukan dan Pencatatan Sipil Kabupaten Padang Pariaman, yang dituangkan dalam nota kesepakatan bersama nomor: B144/Kua.03.5.16/HM.02/03/2018, nomor: $\quad 045 /$ CEL/III/2018 dan nomor: $051 /$ DISDUKCAPIL-2018 tentang Pelayanan Administrasi Nikah Terintegrasi (PANTER) di KUA Kecamatan Enam Lingkung.

Inovasi pelayanan publik PANTER yang dilakukan oleh KUA Kecamatan Enam Lingkung kepada pasangan pengantin yang melangsungkan pernikahan di wilayah kerja KUA Kecamatan Enam Lingkung yang setelah menikah selain mendapatkan Buku Kutipan Akta Nikah juga mendapatkan dokumen kependudukan lainnya. Inovasi PANTER ini dilatar belakangi oleh adanya keinginan peningkatan kualitas inovasi yang dilakukan oleh KUA Kecamatan Enam Lingkung dan juga adanya masyarakat yang sudah melakukan pernikahan tapi tidak mengubah data kependudukan seperti status perkawinan, sehingga masyarakat melakukan pelanggaran syarat pernikahan karena tidak sesuai dengan yang harusnya dicatat dalam dokumen kependudukan. 
Inovasi ini dapat dikatakan telah meningkatkan kualitas pelayanan di KUA Kecamatan Enam Lingkung karena inovasi ini mempermudah masyarakat Kecamatan Enam Lingkung dalam mendapatkan dokumen.

Dahulunya, masyarakat yang sudah melakukan pernikahan dan yang ingin mengubah data kependudukan akan mengurus dokumen kependudukan secara personal dengan langsung mendatangi Kantor Dinas Kependudukan dan Pencatatan Sipil yang berada di Kota Pariaman, hal ini membuat waktu, tenaga, dan uang masyarakat akan keluar lebih banyak, sedangkan dengan PANTER hal itu dapat dikatakan tidak ada, karena pelayanan ini gratis tidak dipungut biaya tambahan selain biaya pengurusan nikah dan masyarakat tidak perlu lagi mengurus dokumen kependudukan ke Dinas Kependudukan dan Pencatatan Sipil yang jauh dan berada di Kota Pariaman.

Melalui pelayanan ini calon pengantin dan keluarga yang baru saja melaksanakan ijab kabul akan mendapatkan beberapa dokumen seperti, 1. Buku Nikah, 2. Kartu Tanda Penduduk, 3. Kartu Keluarga, 4. BPJS Kesehatan (opsional). Dalam inovasi pelayanan PANTER ini adalah bahwa semua dokumen kependudukan itu diberikan secara langsung oleh KUA Kecamatan Enam Lingkung kepada setiap pasangan pengantin yang baru saja melangsungkan pernikahan di wilayah kerja KUA Kecamatan Enam Lingkung tanpa dipungut biaya dan apabila seandainya Kepala Dinas Kependudukan dan Pencatatan Sipil tidak berada ditempat untuk menandatangani dokumen, maka dokumen akan diantarkan melalui Kantor Pos ke alamat calon pengantin perempuan. Semua persyaratan pembuatan dokumen kependudukan bagi calon pengantin maupun pemecahan dokumen untuk orang tua calon pengantin dikirim secara online (daring) oleh KUA Kecamatan Enam Lingkung kepada Dinas Kependudukan dan Pencatatan Sipil Kabupaten Padang Pariaman.

Berkat kemudahan yang diberikan oleh inovasi PANTER ini, KUA Kecamatan Enam Lingkung Kabupaten Padang Pariaman mendapatkan penghargaan KUA Teladan yang dibuktikan dengan keputusan Kanwil Kemenag Provinsi Sumatera Barat nomor 252 tahun 2018 tentang penetapan dan penganugerahan KUA teladan, KUA enam lingkung merupakan KUA yang terpilih sebagai KUA Terbaik I pada Penilaian Kantor Urusan Agama Teladan Tingkat Provinsi Sumatera Barat Tahun 2018 serta mewakili Provinsi Sumatera Barat dalam ajang KUA Teladan se-Indonesia. Sehingga dengan demikian diharapkan inovasi ini dapat menjadi best practice bagi program lainnya yang ada

\section{METODE PENELITIAN}

Penelitian ini menggunakan pendekatan kualitatif, dengan jenis penelitian deskriptif. Penelitian ini dapat menggambarkan secara sistematis, faktual dan akurat mengenai fakta-fakta. Teknik pengumpuan data dalam penelitian ini adalah wawancara dan dokumentasi. Sumber data dalam penelitian ini adalah data primer dan sekunder yang mana data primer merupakan data empiris yang diperoleh dari para informan berdasarkan hasil wawancara, sedangkan data sekunder adalah data yang diperoleh peneliti melalui laporan-laporan atau dokumendokumen yang bersifat informasi tertulis. 
HASIL DAN DISKUSI/ANALISIS

Dalam penelitian ini, peneliti akan mendeskripsikan inovasi pelayanan administrasi nikah terintegrasi di Kantor Urusan Agama Kabupaten Padang Pariaman menggunakan atribut inovasi (Suwarno, 2008) dimana dalam teori ini terdapat lima variabel yang akan dijabarkan sebagai berikut:

\section{Keuntungan Relatif}

$$
\text { Sebuah inovasi dapat }
$$
dikatakan memliki keuntungan apabila inovasi itu mempunyai nilai lebih dan keunggulan dibandingkan dengan pelayanan atau inovasi sebelumnya. Keuntungan relatif dapat diukur dari segi ekonomi, kepuasan dan kenyamanan. Segi ekonomi yang dimaskud secara sederhana merupakan bagian kehidupan tentang keuangan atau biaya hidup. Keuntungan dari segi ekonomi berupa biaya awal yang rendah atau tidak dibebankan sama sekali (Suwarno, 2008). Untuk mendapatkan inovasi PANTER, calon pengantin tidak dipungut biaya sama sekali, sehingga dari segi keuntungan ekonomi para calon pengantin mendapat keuntungan. Tidak hanya bebas biaya, keuntungan ekonomi yang dirasakan masyarakat juga dapat dilihat dari tidak perlunya masyarakat mengeluarkan biaya tambahan untuk transportasi karena letak kantor Disdukcapil Kabupaten Padang Pariaman berada di Kota Pariaman.

Salah satu indikator dalam mengukur keuntungan relatif dari suatu inovasi adalah kenyamanan yang diberikan kepada pengguna inovasi atau masyarakat. Kenyamanan dapat didefinisikan dimana kondisi fisik dan psikologis seseorang merasa baik dan tidak ada gangguan. Dilihat dari aspek fisik maka yang dijelaskan adalah kondisi tempat inovasi itu dilaksanakan. Secara fisik dan lingkungan KUA Kecamatan Enam Lingkung telah memberikan standar kenyamanan fisik seperti adanya front office, ruangan khusus staff serta ruangan untuk sidang dan menikahkan pasangan pengantin. Sayangnya, dalam hal yang berkaitan dengan lingkungan, KUA Kecamatan Enam Lingkung belum merasakan kenyamanan yang seharusnya karena kurangnya fasilitas pendukung seperti kursi dan meja serta kipas angin. Sedangkan untuk kenyamanan sosio kultural berkaitan dengan hubungan interpersonal. Hal ini dilihat bagaimana perlakuan petugas kepada masyarakat yang menggunakan inovasi. Masyarakat yang menggunakan inovasi ini menyatakan bahwa dalam pelaksanaan inovasi ini petugas bersifat baik dan menolong ketika dibutuhkan. Hal ini berkaitan dengan motto KUA Enam Lingkung yakni "PASTI : Profesional, Amanah, Senyum Transparan, Inovatif. Kecamatan Enam Lingkung melayani masyarakat dengan ramah, sopan, santun, baik dan cepat tanpa membedakan pemohon dan memegang teguh prinsip bersih dan melayani".

Dalam inovasi kepuasan pelanggan atau pengguna merupakan hal yang sangat penting, karna jika masyarakat merasa puas dengan layanan yang diberikan maka bisa dikatakan inovasi itu berhasil dan layak untuk dilanjutkan. Kepuasan masyarakat untuk inovasi PANTER ini dilihat dari adanya kemudahan persyaratan, prosedur dan mekanisme dalam layanan PANTER. Pada dasarnya, persyaratan yang harus dipenuhi masyarakat sama seperti sebelumnya. Akan tetapi, adanya kemudahan prosedur dan mekanisme yang diterima 
masyarakat yakni masyarakat hanya perlu mengisi satu form untuk mendapatkan tiga jenis dokumen (Buku Nikah, KTP, dan KK). Selanjutnya kepuasan dapat dilihat dari dari kejelasan jangka waktu pelayanan. Dalam hal ini jangka waktu pelayanan yang dimaksud adalah berapa lama waktu yang dibutuhkan masyarakat mulai dari memasukan berkas hingga mendapatkan dokumen. Pada inovasi ini masyarakat idealnya memasukan berkas 2 minggu sebelum pernikahan dilakukan dan akan mendapatkan dokumen nikah serta dokumen kependudukan setelah ijab qabul dilakukan.

Kepuasan bisa juga dilihat dari kejelasan tarif atau biaya yang dibebankan pada layanan PANTER. Dalam hal ini kejelasan tarif atau biaya yang dimaksud adalah transparansi biaya yang harus dikeluarkan oleh pengguna inovasi PANTER. KUA Kecamatan Enam Lingkung telah menyatakan bahwa KUA merupakan zona integritas yang mana hal ini ditandai dengan dibuatnya poster tentang transparansi biaya seluruh pelayanan yang ada di KUA Kecamatan Enam Lingkung. Begitu juga dengan layanan yang diberikan Disdukcapil Kabupaten Padang Pariaman, dimana semua layanan khususnya layanan yang berkaitan dengan inovasi PANTER sudah jelas biayanya seperti yang bisa dilihat di website Disdukcapil Kabupaten Padang Pariaman (www.dukcapil.padangpariamankab.go. id)

\section{Kesesuaian}

Dalam inovasi, kesesuaian merupakan hal yang penting karena berpengaruh terhadap tingkat adopsi dan keberlanjutan inovasi. Inovasi dibuat berdasarkan kebutuhan masyarakat, sebuah inovasi tidak akan berjalan apabila tidak sesuai dengan kebutuhan masyarakat. Inovasi juga dibuat sesuai dan tidak bertentangan dengan nilai-nilai dan norma-norma yang ada dan berkembang dalam masyarakat serta tidak bertentangan dengan kepercayaan dan keyakinan masyarakat. Selanjutnya, inovasi yang dibuat harus sesuai dengan gagasan atau ide pelayanan yang sebelumnya, yang mana artinya inovasi tidak akan jauh berbeda jenisnya dengan pelayanan dasar yang merupakan tugas dari organisasi atau lembaga yang membuat inovasi ini.

Inovasi PANTER di Kecamatan Enam Lingkung Kabupaten Padang Pariaman telah mengacu terhadap aturan dan kebijakan yang telah ditetapkan sebelumnya, suatu inovasi pelayanan publik maka pelaksanaannya harus mengacu pada peraturan yang ada agar sah secara hukum serta sesuai dengan nilai dan norma yang ada di masyarakat. Jika dikaitkan dengan lembaga maka nilai dan norma yang dilakukan haruslah sesuai dengan azas-azas yang telah ditetapkan oleh peraturan, dalam hal ini yang menjadi acuan adalah Undang Undang Nomor 25 Tahun 2009 yang mana dalam undangundang tersebut terdapat beberapa azas yang salah satunya mudah dan cepat, dan inilah nilai dan norma yang sesuai dengan inovasi PANTER ini karena masyarakat mudah menggunakan inovasi ini dan cepat mendapatkan dokumen kependudukan.

Sebuah inovasi harus sesuai dengan ide atau pelayanan yang sudah ada dan dilaksanakan sebelumnya dalam organisasi atau lembaga tersebut. Walaupun ada beberapa inovasi yang benar benar baru, tapi tidak merubah hakikat dari pelayanan yang diberikan, sesuai dengan pelayanan yang sebelumnya. 
Inovasi PANTER ini menyesesuaikan dengan pelayanan yang sudah ada di KUA Kecamatan Enam Lingkung, yaitu peristiwa nikah. Inovasi ini tidak merubah tujuan dan fungsi dari KUA Kecamatan Enam Lingkung hanya saja mempermudah masyarakat dalam mendapatkan dokumen-dokumen kependudukan. Dalam hal dokumen atau persyaratan tidak ada perubahan, hanya saja catin diharuskan mengisi Formulir Paket PANTER yang diberikan oleh petugas PANTER di Kantor KUA Kecamatan Enam Lingkung. Begitupun dengan layanan yang ada di Disdukcapil Kabupaten Padang Pariaman. Setelah adanya PANTER tidak adanya perubahan yang terjadi pada layanan di Disdukcapil Kabupaten Padang Pariaman karena pelayanan yang diberikan kepada KUA Kecamatan Enam Lingkung sudah sesuai dengan SOP yang ada sebelumnya sehingga tidak mengubah bentuk pelayanan.

\section{Kerumitan}

Kerumitan dalam inovasi dilihat dari bagaimana sebuah inovasi mempunyai tingkat kesulitan, bisa saja sebuah inovasi mempunyai tingkat kerumitan yang lebih besar atau lebih kecil dari pelayanan atau inovasi yang sebelumnya. Kerumitan bisa juga diartikan dengan sebuah kendala yang dihadapi serta kekurangan dari inovasi ini.

Pada pelaksanaan inovasi PANTER, pada dasarnya tidak memberikan kerumitan atau kendala bagi masyarakat yang menggunakannya, justru inovasi ini mempermudah dan membantu masyarakat karena dalam inovasi ini masyarakat tidak dibebani dengan hal yang baru, seperti yang sudah disampaikan sebelumnya bahwa inovasi PANTER ini tidak merubah pelayanan dan syarat-syarat yang sudah ada sebelumnya. Kendala yang terjadi lebih kepada pelaksana inovasi PANTER ini sendiri seperti kurangnya jumlah petugas yang ada di Kantor KUA Kecamatan Enam Lingkung. Kurangnya jumlah petugas tersebut akan terasa disaat jaringan internet sedang down. Karena pada dasarnya pengiriman dokumen oleh petugas KUA kepada Disdukcapil dilakukan secara online. Sehingga apabila jaringan internet down maka mengharuskan petugas KUA yang mengantar langsung dokumen ke Disdukcapil. Hal tersebut akan berdampak pada kinerja petugas, karena terdapatnya kekurangan jumlah petugas. Selain itu, kendala dalam pelaksanaan inovasi PANTER terjadi apabila kepala dukcapil tidak berada dikantor untuk menanda tangani dokumen yang akan diberikan kepada masyarakat, sehingga dokumen tersebut di undur penerbitannya sampai kepala dukcapil menanda tangani dokumen itu, yang menyebabkan dokumen seharusnya diantar oleh petugas Disdukcapil ke KUA Enam Lingkung menjadi diantar oleh POS Indonesia ke alamat catin.

Kendala selanjutnya adalah masyarakat enggan untuk mendaftarkan diri sebagai peserta BPJS Kesehatan, karena menurut peraturan BPJS No 4 Tahun 2014 bahwa setiap pihak yang mendaftarkan dan anggota keluarganya wajib menjadi peserta BPJS Kesehatan, yang artinya semua yang berada dalam KK wajib mendaftar juga menjadi peserta BPJS Kesehatan

\section{Kemungkinan Dicoba}

Sebuah inovasi harus mempunyai sisi keunggulan dan telah teruji serta sudah melalui fase uji publik guna melihat bahwa inovasi bisa dicoba dan digunakan secara berlanjut. Inovasi yang telah melalui 
uji publik akan mempunyai kesempatan untuk dilanjutkan dan semua masyarakat mempunyai kesempatan yang sama untuk mencoba inovasi tersebut.

Inovasi dapat dikatakan teruji keunggulannya jika inovasi tersebut memiliki prestasi yang sudah diraihnya, dengan inovasi PANTER ini KUA Kecamatan Enam Lingkung berhasil menjadi KUA Teladan Terbaik I di Tingkat Provinsi Sumatera Barat berdasarkan Surat Keputusan Kanwil Kemenag No. 252 tahun 2018, serta juga menjadi perwakilan Sumatera Barat dalam KUA Teladan Nasional tahun 2018. , salah satu yang membuat inovasi dapat diterima oleh masyarakat adalah inovasi dengan adanya keunggulan kebaharuan yang ada pada inovasi tersebut (suwarno, 2008). Ketika sebuah inovasi mampu memberikan manfaat atau keunggulan lebih dari inovasi atau pelayanan yang sebelumnya, maka masyarakat akan lebih mudah untuk menerima dan akan tertarik untuk mengikuti atau mengadopsi inovasi tersebut. Dengan adanya keunggulan dan penghargaan yang diraih oleh inovasi PANTER ini membuktikan bahwa inovasi PANTER ini mempunyai nilai kebaharuan dan memang teruji keunggulannya.

Sebelum inovasi ditetapkan menjadi pelayanan tetap, maka dilakukan terlebih dahulu uji publik, dimana uji publik yang dimaksudkan disini adalah memperkenalkan dan mensosialisasikan inovasi PANTER kepada masyarakat. Uji publik inovasi PANTER dilakukan ketika KUA Kecamatan Enam Lingkung melakukan Pelayanan Lapangan Terpadu atau LAYANG PADU yang mana pelayanan ini adalah pelayanan yang dilakukan oleh KUA Kecamatan Enam Lingkung dengan beberapa stakeholder di suatu lapangan yang dilakukan dua kali dalam sebulan, seiringan dengan pelayanan inilah inovasi PANTER disosialisasikan dan diperkenalkan oleh KUA Kecamatan Enam Lingkung kepada masyarakat Kecamatan Enam Lingkung.

Uji publik dilakukan untuk melihat respon dan saran dari masyarakat demi jalannya sebuah inovasi. Sosialisasi dilakukan dengan mengundang masyarakat guna meminta saran tentang inovasi PANTER ini. Dalam sosialisasi inovasi PANTER tidak saja hanya dilakukan oleh KUA Kecamatan Enam Lingkung saja, tetapi beberapa stakeholder yang telah menjalin hubungan kerjasama dengan KUA Kecamatan Enam Lingkung. Hal ini bertujuan agar inovasi PANTER ini tidak hanya menjadi tanggung jawab dari KUA Kecamatan Enam Lingkung saja, tetapi juga menjadi tanggung jawab semua stakeholders yang telah menjalin kerjasama.

\section{Kemudahan Diamati}

Sebuah inovasi harus mudah diamati, yang artinya sejauh mana suatu hasil inovasi yang dicapai dapat dilihat oleh masyarakat, dan dapat dikomunikasikan atau dilihat bagaimana prosesnya sampai hasil yang diinginkan. Sebuah inovasi harus dapat diamati dari segi bagaimana dia bekerja serta menghasilkan sesuatu yang lebih baik dan lebih bermanfaat bagi masyarakat (Suwarno, 2008). Sebuah inovasi harus jelas prosesnya mulai dari ide lalu diwujudkan hingga menciptakan suatu yang bermanfaat dan terukur hasilnya oleh masyarakat. Hal ini bertujuan agar memberikan kepuasan kepada masyarakat. Sebuah inovasi mempunyai proses dan mudah untuk diamati prosesnya serta begitu juga dengan hasil yang dicapai dengan adanya inovasi tersebut. 
Sesuai dengan apa yang telah dilakukan oleh KUA Kecamatan Enam Lingkung setelah MoU ditanda tangani serta inovasi dibuat maka inovasi segera dilaksanakan.

Dalam pelaksanaannya, yang pertama dilakukan oleh masyarakat adalah mendaftarkan permohonannya dan mengisi formulir paket layanan, selanjutnya petugas PANTER mencatat kedalam buku pendaftaran nikah, apabila semua data persyaratan tidak lengkap maka berkas akan dikembalikan kepada catin untuk dilengkapi dan jika semua data lengkap maka petugas PANTER akan memberikan resi pendaftaran kepada catin, lalu petugas PANTER akan mengirimkan data catin yang telah lengkap kepada layanan Disdukcapil secara online atau diantar langsung oleh petugas KUA.

Selanjutnya, petugas PANTER di Disdukcapil Padang Pariaman akan memvalidasi data yang telah dikirimkan PANTER di KUA Kecamatan Enam Lingkung, apabila data valid sesuai dengan database Disdukcapil maka Disdukcapil akan membuat dan mengeluarkan dokumen KK Catin,KTP kedua catin dengan status kawin dan KK pemecah kedua orang tua catin. Seluruh dokumen tersebut diantar langsung oleh petugas bagian PANTER Disdukcapil Kabupaten Padang Pariaman ke KUA Kecamatan Enam Lingkung atau dikirim lewat POS kepada alamat catin perempuan apabila Kepala Disdukcapil tidak berada ditempat untuk menandatangani dokumen tersebut.

$$
\text { Setelah dokumen dari }
$$

Disdukcapil dan KUA selesai maka selanjutnya menunggu hari pernikahan, sesuai dengan tradisi yang ada sebelum ijab qabul dilaksanakan penghulu akan memberikan bekal atau nasehat pernikahan terakhir. Akan tetapi masyarakat tidak dapat melihat secara langsung proses pelaksanaan inovasi PANTER ini, seperti sejauh mana berkas mereka diproses sehingga menjadi catatan perbaikan untuk inovasi PANTER ini. Sebuah inovasi harus mempunyai hasil yang dapat dilihat dengan jelas dan terukur.

Artinya, sebuah inovasi mempunyai hasil yang dapat dilihat dan dirasakan serta dapat diukur. Dalam inovasi PANTER ini hasil nyata yang dapat dilihat adalah bagaimana masyarakat mendapatkan dokumen pernikahan dan dokumen kependudukan yang baru, serta bagaimana rasa puas dan dapat diterima oleh masyarakat pengguna inovasi ini, dalam hal ini dapat dilihat dengan adanya pemberian dokumen langsung oleh Kepala KUA Kecamatan Enam Lingkung kepada pengantin yang telah melaksanakan ijab qabul.

Selain inovasi ini dapat dilihat hasilnya secara langsung, Inovasi ini juga mempunyai tujuan untuk meningkatkan kualitas pelayanan dan kepuasan masyarakat, maka inovasi ini tidak diukur dengan angka karena tidak ada korelasi antara inovasi PANTER dengan jumlah yang ingin menikah.

Sedangkan untuk Disdukcapil Kabupaten Padang Pariaman hasil dari inovasi ini adalah membuat masyarakat menjadi tertib administrasi, data kependudukan Kecamatan Enam Lingkung yang berkaitan dengan status, pernikahan, pemecahan KK menjadi teratur.

\section{KESIMPULAN}

Berdasarkan penjelasan temuan dan analisis dapat peneliti simpulkan bahwa Inovasi PANTER merupakan inovasi dibidang pelayanan dokumen pernikahan dan kependudukan yang digagas oleh KUA Kecamatan Enam Lingkung 
Kabupaten Padang Pariaman dengan beberapa stakeholder. Secara umum tujuan inovasi ini adalah untuk memudahkan masyarakat dalam mendapatkan dokumen kependudukan seperti KTP dan KK baru bagi masyarakat yang melaksanakan pernikahan, dan juga membuat tertib administrasi untuk masyarakat. Namun masih ada beberapa hal yang belum maksimal dalam melaksanakan inovasi ini seperti dari segi kenyamanan masyarakat yang ingin menggunakan inovasi ini serta kurangnya sarana dan prasana yang mendukung petugas KUA Kecamatan Enam Lingkung ini dalam melaksanakan inovasi PANTER.

\section{REFERENSI}

Jurnal:

Ananda, Putera, dkk. 2020. Inovasi Pelayanan Kesehatan di Rumah Sakit Umum Daerah Kota Pariaman, Publik (Jurnal Administrasi) Vol 8 (2), Hal 167 $-179$

Andhika, Lesmana. 2018. Elemen dan Faktor Governansi Inovasi Pelayanan. Publik Pemerintah, Jurnal Kelitbangan, Vol 6, No 3, Hal 208

Djamrut, Dayang. 2015. Inovasi Pelayanan Publik di Kecamatan Sungai Kunjang Kota Samarinda, eJournal Ilmu Pemerintahan, Vol 3, No 3, Hal 1472-1486

Hisbani, Karim, dkk, 2015. Penerapan Inovasi Pelayanan Publik Di Dinas Kependudukan Dan Catatan Sipil Kabupaten Enrekang, Kolaborasi Jurnal Administrasi Publik, Vol 1, No 3, Hal 265-277
Triwahyuni, Putera, dkk. 2020. Inovasi Pelayanan Kesehatan Kelas Imud di Puskesmas Padang Pasir, Kecamatan Padang Barat, Kota Padang, Sumatera Barat, JPP, Vol 6, No 1, Hal 13-18

Yuliana, Putera, dkk. 2020. Inovasi Pelayanan Kesehatan Public Safety Center 119 (Psc 119) Smash Care's Di Kota Solok, JIAP, Vol 8, No 1, Hal 265-271

Informasi Manajemen Sumber Daya Manusia. Jakarta: Grasindo.

Muluk, Khairul M.R. 2008. Knowledge Management: Kunci Sukses Inovasi Pemerintah Daerah. Malang: Banyumedia Pulishing

Ratminto, Winarsih. 2006. Manajemen Pelayanan. Yogyakarta: Pustaka pelajar.

Rogers, Everett M. 1983. Diffusion of Innovations Third Edition. New York: The Free Press

Sedarmayanti. 2014. Good Governance Bagian Kedua, Bandung: CV Mandar Maju

Sinambela, Lijan Poltak, dkk. 2016. Reformasi Pelayanan Publik: Teori, Kebijakan, dan Implementasi. Jakarta: PT Bumi Aksara

Stephen P. Robbins, Timothy A. Judge. 2008. Perilaku Organisasi. Jakarta: Salemba Empat

Suwarno, Yogi. 2008. Inovasi di Sektor Publik. Jakarta: STIALAN 